\title{
Sports Allegory
}

\author{
Eugene Goodheart
}

Published online: 4 October 2011

(C) Springer Science+Business Media, LLC 2011

"Frank, were you ever an athlete?" Walter said forthrightly after our long and studious staring

"Just an athletic supporter, Walter," I said and gave him a grin to set him at his ease.

Richard Ford, The Sportswriter

The first section of the newspaper I turn to is the sports section. I spend hours in front of the television set watching football, baseball, basketball, and even golf. My best times in adolescence were when playing punch ball and touch football. I no longer play ball, but I am an addicted spectator. The last time on a tennis court I had to take a timeout after every rally to catch my breath, and I say nothing of the quality of my play. Reading about and watching sports have become huge time-consuming inactivities. Sports have often entered my speech and my writing (as they have with millions of others) as metaphor. We expect people at times of need and crisis "to step up to the plate." When we fail we "strike out." Or, as a recent Director of Central Intelligence said to the former President, the reliability of information about weapons of mass destruction in Iraq was "a slam dunk." The phrases are clichés, almost dead metaphors, when we speak them unthinkingly. They are abbreviations for our experiences that require no exercise of our imaginations. Just a little thought, imagination and courage would have inhibited the Director from speaking of the diligent collection of information as a "slam dunk," the swiftest, the most athletic and most exhibitionistic of spectacular moves in team sports. Or perhaps the very phrase was intended as

E. Goodheart $(\bowtie)$

Department of English, Brandeis University,

Waltham, MA 02454, USA

e-mail: goodhear@brandeis.edu distraction from the truth. The patient teamwork on the basketball court that leads to a high percentage basket is like that in genuine information gathering, which leads to truth. The slam dunk says "to hell with all that," as the player dribbles to the basket oblivious of everything around him. The perplexed face of the President stood in the way and the Director simply leaped over him to settle the matter. As it turned out, he missed the basket, but no one noticed, or cared to notice, until years later. Am I digressing, having hardly begun? Or is this a glimpse of how the culture of sports and its language enters our non-sporting lives.

As a spectator I invest my emotions on one side or the other. The activity of the spectator is being a fan, an enthusiast for a team. Without the knowledge and verbal talent to describe and analyze the action of a baseball or football or basketball game, what of interest could I write about? There is the drug-like effect of surrendering oneself to the action, marveling at the performances and the risks that others take. I suppose I could contribute to the literature of addiction by describing endless hours of spectating.

If I were a storyteller, a writer of novels or epics, I would find a place for sports as part of the lives of my characters. In The Iliad, the greatest of all epics, games interrupt the narrative of war. Though they are a respite from the life and death encounters on the battlefield, no reasonably alert reader can fail to get the message: in a war the games are battles waged by other less harmful means. The victorious players exult in their triumphs, the losers despair, resent their defeats, and dream of revenge. Sometimes the boundary between life and the game disappears and the loser takes revenge on the winner. A fight breaks out and someone is injured - or killed. The national team loses in a soccer match and mayhem ensues. Stores are vandalized, cars overturned and set on fire, and innocent bystanders 
suffer injuries and die. An athlete is paralyzed in a collision on the football field or dies as a result of being hit in the head by a baseball. But such events, whether frequent or not, are incidental to the game, though not to the lives of the players. The essence of war is killing or being killed. There's the old joke of the Jewish enlisted man who comes under fire on the battlefield, turns around and runs away. His sergeant intercepts him: "hey, Finkelstein, where do you think you're going?" Pointing back to where the battle is raging, the frightened Finkelstein responds: "You can get killed there!" War, he has been shocked to learn, is no game.

In a time like ours, when the news of the world is relentlessly alarming and depressing (when was the news not alarming and depressing?), games whether played or watched are necessary to our psychic health. They belong to the circuses that supplement the bread that society provides its citizens. (I don't understand the psychology of those who have no interest at all in the sports. Perhaps some valve in their brains was never turned on.) As the news anchor turns to the sports reporter, whatever gravitas the anchor may possess evaporates, the voice lightens and even when the home team loses, it speaks in a tone of mock distress and disappointment. We have been taught from childhood not to be sore losers in the realization that it is only a game. A grandparent playing with his grandson learns how much easier it is to teach him the rules than to accept defeat. The game is the strongest reality he inhabits. A fan says: "I hate the Yankees" and she laughs; one doesn't laugh after confessing to real hatred. The rabid fans who rail against the losers on sports radio and threaten mayhem if the losing doesn't stop are the childish adults who never learned to distinguish between real life and a game.

As a fan I am cheered by the victory of my team, downcast by defeat, but the range of my emotions is nothing like the experience of the news of the world. Nor is it anything like the troubles of our personal lives. Unlike the entertainments of the cinema and the stage in which we are given fictions of reality, the games we watch are antidotes to its afflictions. What if life were simply a game with rules to be followed and wins and losses accepted by competitors with more or less grace? Much of our larger conception of life as we know it would remain: the work ethic (professional athletes are assiduous practitioners of their craft), talent, skill, knowledge of rules, suspense, joy in victory, disappointment in defeat.

For the spectator the game is the closest thing we have to utopia. I say for the spectator, because athletes in sports such as boxing and football risk life and limb. (They also know the grind of daily reality in training mind and body.) The most serious writing about sport is less about the sport itself than its consequences for the athlete: the injured and permanently disabled football player, the boxer corrupted by the mob, the depression that ensues after a career has ended. While the game is played, the player falls to the ground injured, often seriously injured, but for the spectator the sense of reality of the player's suffering is a brief suspension of our pleasure in the game as he is carted off the field. The injured player may look up at the stands and raise his arm to the cheers of the crowd as if the injury itself is a heroic deed. On the sidelines players gather in a huddle to pray for their fallen comrade. But, on the field and during the game, no sentiment is to be wasted on the suffering of the player. After the game, the overwhelming question is what the injury may mean for the future success of the team. As we watch the game, we thrill to the moment: the wide receiver making a one handed catch of the football; the boxer, a whirling dervish of fists striking with accuracy an opponent; the guard, dribbling and weaving down the basketball court and leaping to the basket as he finger rolls the ball and makes the basket. Watching is expectation, and expectation is of the moment of release and achievement. The television camera focuses on the face of young woman in a sports jersey, face decorated with a team logo, fists tensely pressed together against her face, eyes excitedly and pleasurably concentrated and anxious. To be sure, during the watching, there are the longueurs that fill every aspect of our lives. Many actual games are in their mediocrity failed utopias.

Of course, the game that engages the interests of millions of people is never only a game. Two nations at odds begin to reconcile when the national teams of the countries meet in a sporting event. Ping-pong brought the United States and China together. Competitors, like soldiers at war, are expected to sacrifice everything for victory. Winning, Coach Vince Lombardi of the Green Bay Packers tells us, is the only thing. The competitor who loses is disgraced. No entertaining trifle for professional athletes (or for many fans), the game is an intensification of life, an antidote to its formlessness. Millions of people become fans, or better, patriots of their home team. The leaders of the country have started a war that has divided the country, but you would not know it in the stadium as everyone rises to sing the Star Spangled Banner. Sitting in the stands, the spectator experiences a sense of solidarity with others that has nothing to do with friendship or love. And yet nothing quite compares with the dizzy ecstasy of a crowd witnessing a game-winning home run in the bottom of the ninth inning. After the Boston Red Sox won the World Series for the first time in eighty-six years, the whole city turned out for the parade that celebrated the victory. A friend who participated in the parade looked into the face of the crowd and saw to his alarm the ecstatic joy that could have turned to rage if the outcome had been different. The sports crowd, I hear a critic of my enthusiasm say, is fertile ground for fascism. Recall the vast rallies of the Nazis.

Divinity is in the athlete or the team and the spectator is the observant laity at the shrine. I am moving toward a 
familiar idea about what holds the many millions of us (those consumed by watching and cheering) in thrall to the athlete as he performs on the battlefield. The professional athlete's performance in modern times may be the only survival of the ancient warrior whose epical feats are performed in pursuit of glory. When Achilles strikes out against his adversaries with a known history of heroic deeds, he does so in the eyes of gods and men. Heroic action cannot take place in anonymity, and the agents of modern warfare, no matter how brave or how skilled, are anonymous creatures whose actions are for the most part deprived of the light in which they can be seen and celebrated. The star athlete steps on the field or court or rink or course like the ancient warrior with a pedigree of achievement. The knowing spectator who follows his career can recite the home runs, the touchdowns, the goals scored. The modern athlete does not have the high risk of death and injury of the soldier on the battlefield, but like that of the ancient warrior it exists as it does not for us ordinary mortals. He also risks the humiliations of cowardice and defeat in the eyes of millions of onlookers. Think of it, a hundred thousand pairs of eyes and voices in the stands on a Saturday afternoon in a college stadium joining together screaming, celebrating, despairing as the running back plows through the defensive line, stutter steps, weaves around his opponents as he races toward the goal line or as the quarterback lofts a high arcing pass down field, slightly ahead of the reach of the receiver who tips the ball one handed into his chest and rolls over in a somersault. (In Ravelstein Saul Bellow represents the moment of aspiration and achievement in Michael Jordan's action on the basketball court: "He could suspend himself in the air out of the reach of blockers, and you could trace his deliberation in his actions, with time enough to change hands while he soared - a man who earned $\$ 80$ million a year, not a cult figure but a hero who moved the hearts of masses.") The pitcher in the ninth inning strikes out the last batter, and as he walks off the mound, he raises his head to the sky, points to it and then crosses himself. At every moment of his time in the game he is being watched by millions. He knows too when he is on his game that the divine afflatus has descended.

Shy or even timid as he may be in his private life and in his speech, he is a radiant presence on the field. Even those of us sitting alone or together on the couch in the television room are somehow drawn in. We have all become a community of worshippers. After the game, athletes step forward as testifiers to their own achievements, coaches as the priestly interpreters of the text of the game, almost invariably expressing themselves in a language banal and uninteresting. "We pulled together as a team." "We take every game one at a time." "I want to thank God." It is not the words that we hear, but the athlete, graceful, muscular, sweating, proud or humble, as the case may be, whom we contemplate. The interviewer listens solemnly, solecisms are everywhere in the athlete's speech, but they do not compromise the conversation. The athlete is exempt from the judgments we pass on politicians and entertainers. The language we judge is the poise and movement of the athlete's body. We do pass judgment when on the field the athlete hesitates where he should be decisive or when he prematurely makes his move or fails to see an opening. The successful athlete thanks God or Jesus, and we do not mock him, as we might mock a politician. Believers or not, we know that the athlete needs his Deity. Where the athlete is concerned, we are in a church of idolatry.

It is a church based on, or as many would say corrupted by, commerce. Of course, without the commercials that interrupt the game, there would be no game in the modern epic fashion. Commercials create the enormous audience. The interruptions are like comic interludes in a drama. But they are something more: glimpses of ourselves, munching popcorn, swilling beer, safely imitating the athlete on the field in our noises and swaggering as we watch the game. The screen affectionately mocks us in the act of watching the game. We vicariously enter the movements and struggles of the athletes without experiencing the shock or pain of battle. The athlete appears in a commercial surrounded by a crowd of adoring children and adults. $\mathrm{He}$ makes his move to the basket; he swings his bat or golf club and drives the ball far in a high arc. The crowd gazes in awe. The crowd in the commercial, standing for us, is a gathering of aesthetes, observing the artist. Or the athlete appears as benefactor, driving a truckload of basketballs to a court in the inner city. As he turns to leave he calls out to the adult coach and tosses him the keys to the truck as a gift. The athlete jumps on a bicycle and pedals off to the horizon, a god dispensing grace. My high literary sense of commercial kitsch doesn't have a chance against the seduction. We tend to discount the athlete's misbehavior off the field, unless it is murder or serious bodily harm to others. (The epic hero went on murderous rages, at times even attacking the gods, which we accept as the excess of his greatness.) We are less forgiving of cheating and dirty play on the field. Toward the slam dunking diva on the basketball court we feel ambivalent, unless his showboating wins the game. The star player who sits down on the bench and refuses to play the game because the team has not made him the center of attention is an old story: he is Achilles redivivus, sulking in his tent, because his preeminence has been affronted.

We watch the gifted athlete without envy, knowing that he exists in a space that we can never enter, grateful that such a space exists for our pleasure. We experience the downfall of a political leader, the CEO of a company with schadenfreude, 
perhaps from a sentiment about their unmerited success and from a sense that they succeeded to a place that we might have achieved, if we possessed their brazenness and luck. We may wonder at the huge salaries of star athletes and whether their performances merit them, but for the most part we are grateful for the pleasure they give us in performance. When we learn of the tragic aftermath of their careers, they become martyrs to our appetite for the spectacle of their performances. Like the ancient warriors on the battlefield, they do not survive their youth, or they often leave the game with wrecked lives. To realize his heroism, Achilles must die young; the modern athlete survives his battlefield, but his later life is often a downward trajectory, usually as invisible to the world as his youth was visible. The pathos of sports occurs after the game, when we see and learn about the shambles of mind and body of an athlete who may have barely reached middle age.

What about defeat and its aftermath? The team loses, the rushing back fumbles at a crucial moment, the pass is intercepted, the hitter strikes out with the bases loaded: the reporter assaults the athlete with questions about his failure. The athlete speaks of his disappointment with himself in the scripted language provided by his coaches. "We need to learn from our mistakes and look forward to the next game. It wasn't $X$ who lost the game, we all did our share. We can't keep our heads down. It's only one game." The reporter finds a different way of asking the same question, probing the wound. The athlete maintains or tries to maintain his dignity. Where is the fan, where am I in all this? With the reporter or the athlete? Each fan is different. I am with the athlete, familiar as I am with the sense of failure. I, who have taught and lectured but stumbled in my speech, am incredulous at the command the athlete normally displays. The ball is hit hard down the third base line, the third baseman instinctively finds the ball in the pocket of his glove and fires hard and straight to the first baseman. Sometimes the throw is too high or too low or too wide. He is not quite the pianist whose fingers unerringly and with blinding speed find the keys of the piano in perfect rhythm, or the actor who never forgets his lines, but he is of their order. (The pianist may flub a passage, but only the most discerning ear catches it. Errors are dramatically visible to all on the sports field.) It irks me to see the mediocre talents of the press goad and wheedle the player who has failed in his performance. Schadenfreude is staple of professional sports reporters, many of whom are probably failed athletes.

After the game the sports pundits gather to dissect it. There is only so much of substance that can be said, so they repeat themselves again and again as if they are performing a ritual or singing a refrain, and each time the same magical image of the splendid catch or run or tackle is shown again and again and again. Or we may be shown a receiver dropping a pass or a linesman missing a tackle as if we were being constantly reminded about the consequence of sinning. We are in an orthodox church in which the liturgy is long and every refrain is repeated ad... Early into what one television channel calls "the fifth quarter," in which the pundits rehash every move made on the football field, I have learned everything that I need to know about the game, but I continue to watch and listen to all the repetitions. I can't get enough of it.

I hear the voice mocking my enthusiasm, casting me among the benighted screamers and beer swillers. For all my literary pretensions, shouldn't I hear in the solidarity of the fans singing the Star Spangled Banner the music of jingoism? Aren't circuses a diversion from the serious social and political problems that confront us? I hear the voice, but can't be shamed out of my enthusiasm.

The news of the day (local, national, world) is at its most dramatic a spectacle of disaster, scandal and vituperation. I find myself watching it in all its repetitions as if it were a game badly played. Perhaps our political life could learn from the game well played: training one's mind and body to execute a plan, abiding by the rules and by the decisions of an impartial umpire, gracefully accepting defeat as well as victory. At the end of a game the players, who fought hard against each other meet and shake hands, even embrace. Nations at war may come together, negotiate and end the war. But the duration of the war has no time constraints, except the exhaustion of the adversaries. There was a time when the leaders of warring parties stepped forward and fought to end the war. The duel was the game that allowed thousands to survive. In ordinary life away from the battlefield, the game, even with its brutalities, is a model of justice and fairness. Its conditions are equality of opportunity, qualified only by the acceptance of differences in talent and ability. At this moment in our history, at least on the sports field there is no need for affirmative action. Everyone starts at ground zero, and talent, hard work and luck determine the outcome. The athlete is the headlong risk taker, at once disciplined and reckless. Though he may challenge an umpires ruling, he never questions the rules of the game: his courage takes place within the rules. When he fails in a game that is fairly played, he can only fault himself or acknowledge the superiority of the winner, never fault the system. Those who play the game go into it without the benefit of an inheritance, except of course for their physical and mental skills. It is meritocracy. Nothing from the past gives an advantage to the first pitch, the first kickoff, the first tee shot, the first toss of the basketball between the centers.

Eugene Goodheart is Edytha Macy Gross Professor of Humanities Emeritus at Brandeis University. He is the author of many books of literary and cultural criticism as well as a memoir, Confessions of a Secular Jew. 